\title{
Influence of Microstructure on Beneficiation of Low-Grade Siliceous Manganese Ore from Orissa, India
}

\author{
Patitapaban Mishra ${ }^{1}$, Birendra Kumar Mohapatra ${ }^{2}$, Pradeep Kumar Mallick ${ }^{2}$, Khageswar Mahanta ${ }^{3}$ \\ ${ }^{1}$ Ravenshaw University, Cuttack, India \\ ${ }^{2}$ Institute of Minerals and Materials Technology, Bhubaneswar, India \\ ${ }^{3}$ OMDC Ltd., Thakurani, Orissa, India \\ Email: p_geology@yahoo.co.in
}

Received December 10, 2012; revised January 23, 2013; accepted January 31, 2013

Copyright (C) 2013 Patitapaban Mishra et al. This is an open access article distributed under the Creative Commons Attribution License, which permits unrestricted use, distribution, and reproduction in any medium, provided the original work is properly cited.

\begin{abstract}
Two low-grade siliceous manganese ores such 1) siliceous crystalline and 2) siliceous cherty types from north Orissa, India was mineralogically characterized and investigated for their possible upgradation. Both the Mn-ore types were subjected to different physical beneficiation techniques under identical conditions and results reported. The results revealed that in the case of low-grade siliceous crystalline type Mn-ore a feed having $26 \% \mathrm{Mn}$ could be upgraded to more than $45 \%$ Mn by dry magnetic separation with $69 \%$ recovery at 1.00 tesla magnetic intensity. But the cherty type Mnore could not respond well to any of the beneficiation techniques, particularly dry magnetic separation, because of poor liberation even at a size fraction below 100 mesh, though the other type gives best result at this size fraction.
\end{abstract}

Keywords: Siliceous Manganese Ore; Microstructure; Beneficiation

\section{Introduction}

The manganese deposits of Bonai-Keonjhar belt in the Banded Iron Formation of Iron Ore Group occupy a significant position in mineral wealth of Orissa, Eastern India. The low to medium-grade manganese ores produced from this belt have low phosphorus content in contrast to the other two manganese deposits of Orissa associated with the Gangpur Group and the Khondalite Group. The low-grade Mn-ore of Bonai-Keonjhar belt can be classified on the basis of major matrix/gangue into 1) siliceous; 2) ferruginous; and 3) aluminous types [1]. Out of the 5 lakh tones [2] of Mn-ore that is produced annually in Orissa, $50 \%$ of it is of low-grade category (Mn: $25 \%-35 \%$ ) and siliceous variety occupies a sizeable volume ( $20 \%)$.

Detailed mineralogical and textural studies on the lowgrade siliceous Mn-ores from the above belt revealed that there are two contrasting types of siliceous Mn-ores viz. siliceous crystalline and siliceous cherty types. These two types of low-grade siliceous Mn-ores from Orissa Mineral Development Corporation (OMDC) lease hold were studied under identical physical beneficiation techniques to utilize them and make suitable value addition. The influence of microstructure on the liberation size of $\mathrm{Mn}$-ore and gangue and their role in the beneficiation process was investigated and reported in this paper.

\section{Materials and Methods}

Around one tone each of representative low-grade siliceous manganese ore samples were collected from BhootRiver side (siliceous crystalline) and Mushaghar (siliceous cherty) lease-hold of M/s OMDC Ltd. Barbil, Orissa. All the samples were crushed to below $2 \mathrm{~mm}$ size by roll crusher at different gap settings and classified into different size fractions using standard test sieve viz. 1 $\mathrm{mm}, 0.5 \mathrm{~mm}, 0.25 \mathrm{~mm}, 0.15 \mathrm{~mm}$ and $0.075 \mathrm{~mm}$.

The mineralogical characterization was carried out using optical microscope (Letiz make), X-ray diffractometry (Philips make) and electron probe microanalyser JXA-8100. Detail beneficiation studies were carried out using $1016 \times 437 \mathrm{~mm}$ Denver Wilfley laboratory table supplied by M/s DENVER, USA.

High intensity dry belt magnetic separator of type LOG 1.4 SEP operated at 50 Dc Volt and 4.17 Dc amp. current, suitable for fine particle separation, (supplied by Boxmag Rapid Ltd., Birmingham, England) was employed for magnetic separation. The magnetic intensity was varied between 0.73 and 1.23 tesla. Dry samples of closed size fractions were continuously fed to the belt magnetic separator by vibrating feeder at controlled rate 
(6 rpm). All the products obtained from each experiment were collected separately, dried, weighed and analyzed for $\mathrm{Mn}, \mathrm{Fe}$ and selected samples for $\mathrm{SiO}_{2}$.

\section{Results and Interpretation}

\subsection{Mineralogical Characteristics}

The low-grade siliceous crystalline type and cherty/ amorphous type of Mn-ores from Bonai-Keonjhar belt were mineralogically studied with the help of X-ray diffraction and optical microscopy. Megascopically, the siliceous crystalline type of Mn-ore exhibit 1) large saccaroidal crystalline quartz with Mn infilling (Figure 1(A)) and 2) fine granular quartz with $\mathrm{Mn}$ infilling (Figure 1(B)). On the other hand, the siliceous cherty type contains a) alternate lamina of Mn-ore and cryptocrystalline silica (Figure 1(C)) and b) fine layering between Mn-ore and cherty silica, veins of Manganese often ramify within silica matrix (Figure 1(D)). X-ray diffraction studies on both the type of samples revealed that in the crystalline type pyrolusite constitutes the major Mn-phase with subordinate cryptomelane and quartz the only gangue mineral. On the other hand, the cherty type showed pyrolusite and cryptomelane as major Mn-phases with minor hematite. Quartz along with minor kaolinite constituted gangue phases in the cherty type.

The two types of ores exhibited distinct textural peculiarities. The siliceous crystalline type contained 1) large bladed crystals of pyrolusite having sharp contact relationship with quartz (Figure 2(A)), and 2) thin veins of

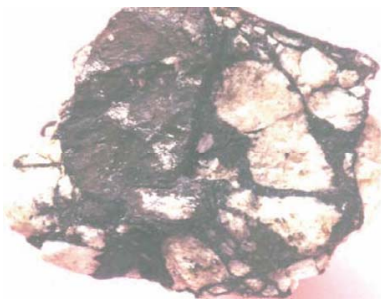

(A)

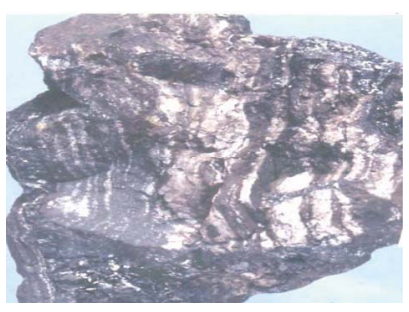

(C)

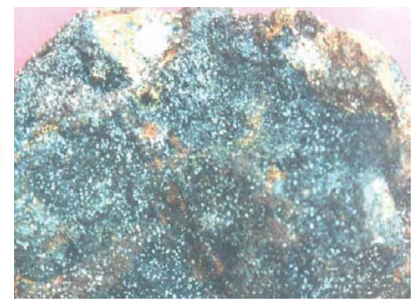

(B)

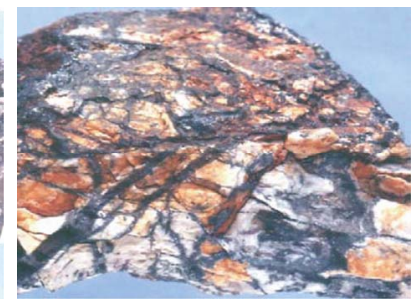

(D)
Figure 1. Photomicrographs of low-grade siliceous Mn-ore. (A), (B) crystalline silica, (C), (D) cherty silica. (A) Manganese infilling within large saccaroidal quartz grains; (B) Fine granular quartz filling the intergranular space of manganese minerals; (C) Dissemination of crystalline quartz grains within massive manganese ore; (D) Alternate lamina of cherty silica and Mn-minerals. cryptomelane traversed through quartz (Figure 2(B)). In the siliceous cherty type a) thick veins of cryptomelane ramifying through siliceous matrix (Figure 2(C)), and b) manganese minerals filling the inter-granular space of cherty rock (Figure 2(D)).

\subsection{Physical and Chemical Characteristics}

The low-grade siliceous ROM sample from Bhoot-Riverside (crystalline type) and Mushaghar (cherty type) were crushed separately and subjected to sieve analysis using standard test sieves of 1000, 500, 250, $150 \& 75$ $\mu \mathrm{m}$ size. Each fraction was weighed and analyzed for $\mathrm{Mn}$, $\mathrm{Fe}$ and selected samples for $\mathrm{SiO}_{2}$. The results of the size and chemical analyses of bulk (considered as feed) and fractionated materials for both the samples are shown in Tables 1(A) and (B). It is clear from the table that both iron and manganese are almost uniformly distributed in all the size fractions.

\subsection{Beneficiation Characteristics}

The size classified samples from both the low-grade siliceous $\mathrm{Mn}$-ore types were subjected to various physical beneficiation techniques under identical conditions. Different methods followed and the results obtained are discussed below.

\subsubsection{Tabling Studies}

Experiments with a mineral separator indicated that gravity technique can be adopted to recover Mn values in

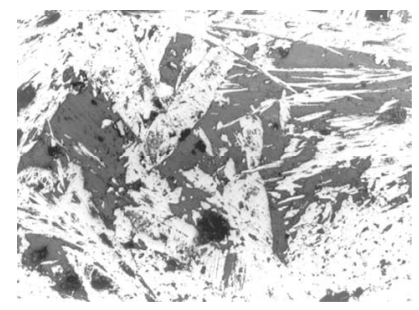

(A)

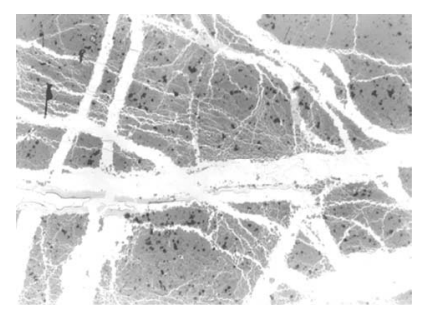

(C)

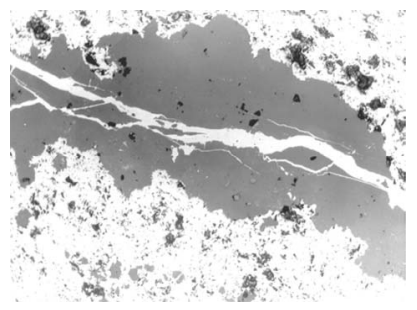

(B)

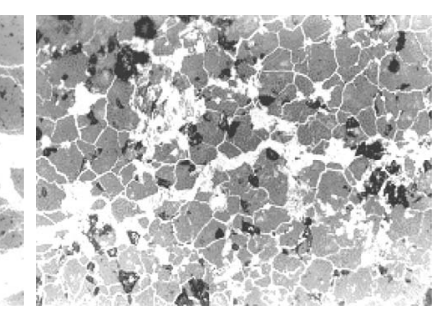

(D)
Figure 2. Microphotographs of manganese minerals showing different micro-texture $\times \mathbf{2 0 0}$. (A) Large bladed crystals pyrolusite having sharp contact with quartz; (B) Thin veins of cryptomelane traversing silica matrix; (C) Brecciated fragment of cryptomelane disseminated over quartz grains; (D) Cryptomelane veins of different thickness ramify over siliceous matrix. 
Table 1. (A) Size and chemical analysis of low-grade siliceous (crystalline) Mn-ore; (B) Size and chemical analysis of low-grade siliceous (cherty) Mn-ore.

(A)

\begin{tabular}{ccccc}
\hline Size, in $\mu \mathrm{m}$ & $\mathrm{wt} \%$ & $\mathrm{Mn} \%$ & $\mathrm{Fe} \%$ & $\mathrm{SiO}_{2} \%$ \\
\hline Bulk & - & 26.41 & 2.78 & 32.42 \\
$-1000+500$ & 40.1 & 24.84 & 2.78 & 34.93 \\
$-500+250$ & 33.4 & 25.47 & 2.92 & 33.78 \\
$-250+150$ & 9.5 & 28.93 & 3.06 & 27.98 \\
$-150+75$ & 9.4 & 28.93 & 3.06 & 27.49 \\
-75 & 7.6 & 27.00 & 4.22 & 32.11 \\
Head & 100 & 25.96 & 2.98 & 32.95 \\
\hline & & $(\mathrm{B})$ & & \\
\hline Size, in $\mu \mathrm{m}$ & $\mathrm{wt} \%$ & $\mathrm{Mn} \%$ & $\mathrm{Fe} \%$ & $\mathrm{SiO}_{2} \%$ \\
\hline Bulk & & 25.1 & 7.6 & 34 \\
$-1000+500$ & 42 & 25.8 & 8.2 & 32.5 \\
$-500+250$ & 26 & 25.2 & 7.8 & 34.0 \\
$-250+150$ & 8 & 24.5 & 7.3 & 35.8 \\
$-150+75$ & 10 & 24.8 & 8.2 & 34.1 \\
-75 & 14 & 23.8 & 7.3 & 36.9 \\
Head & 100 & 25.2 & 7.7 & 34.6 \\
\hline
\end{tabular}

general from both the low-grade siliceous Mn-ore types but better recovery could only be achieved below 500 $\mu \mathrm{m}$. Therefore, both the representative samples were ground to below $500 \mu \mathrm{m}$ size and classified each into $-500+150 \mu \mathrm{m} \&-150 \mu \mathrm{m}$. These fractions were subjected to tabling studies and results are shown in Tables 2(A) and (B). though the crystalline type could be upgraded to $42 \% \mathrm{Mn}$ at $40 \%$ recovery in coarser fraction the cherty type did not respond to tabling.

\subsubsection{Dry Magnetic Separation}

All the size fractions from both the Mn-ore types were subjected to dry magnetic separation at different magnetic intensities viz. 0.73 tesla, 1.00 tesla and 1.23 tesla to assess its magnetic susceptibility. The analytical results obtained for the magnetic products at different magnetic intensities for both samples are presented in Tables 3(A) and (B). It is observed from the table that on an average a product having $45 \% \mathrm{Mn}$ at $69 \%$ recovery can be obtained at 1.00 tesla for all the size fractions in case of crystalline type, but the cherty type could only be upgraded to a product of $34 \% \mathrm{Mn}$ at 1.00 tesla.

\section{Discussion}

Mineralogical characterization of both the types of low-
Table 2. (A) Results of tabling studies of low-grade siliceous (crystalline) Mn-ore. (a) Tabling results of $-500+150 \mu \mathrm{m}$ sample; (b) Tabling results of $-150 \mu \mathrm{m}$ sample; (B) Results of tabling studies of low-grade siliceous (cherty) Mn-ore. (a) Tabling results of $-500+150 \mu \mathrm{m}$ sample; (b) Tabling results of $-150 \mu \mathrm{m}$ sample.

\begin{tabular}{cccccc}
\multicolumn{5}{c}{$\begin{array}{c}\text { (A) } \\
\text { (a) }\end{array}$} \\
\hline Details & $\mathrm{wt} \%$ & $\mathrm{Mn} \%$ & $\mathrm{Fe} \%$ & $\mathrm{SiO}_{2} \%$ & $\mathrm{Mn} \mathrm{Rec.} \%$ \\
\hline Concentrate & 21.1 & 42.05 & 4.34 & 12.3 & 40.7 \\
Middling & 51.1 & 19.17 & 2.26 & 51.5 & 44.9 \\
Tailing & 27.8 & 11.28 & 1.88 & 64.5 & 14.4 \\
\hline
\end{tabular}

(b)

\begin{tabular}{cccccc}
\hline Details & wt $\%$ & $\mathrm{Mn} \%$ & $\mathrm{Fe} \%$ & $\mathrm{SiO}_{2} \%$ & $\mathrm{Mn} \mathrm{Rec.} \%$ \\
\hline Concentrate & 18.0 & 38.25 & 3.89 & 18.9 & 26.4 \\
Middling & 5.6 & 20.16 & 2.22 & 49.8 & 4.3 \\
Tailing & 76.4 & 23.64 & 2.50 & 44.1 & 69.3 \\
Head & 100.0 & 26.07 & 2.73 & & 100 \\
\hline
\end{tabular}

(B)

(a)

\begin{tabular}{cccccc}
\hline Details & $\mathrm{wt} \%$ & $\mathrm{Mn} \%$ & $\mathrm{Fe} \%$ & $\mathrm{SiO}_{2} \%$ & $\mathrm{Mn} \mathrm{Rec} \%$ \\
\hline Concentrate & 14.9 & 30.7 & 14.9 & 15.2 & 17.4 \\
Middling & 66.7 & 27.5 & 10.9 & 25.9 & 70.0 \\
Tailing & 18.4 & 18.0 & 5.9 & 48.1 & 12.6 \\
\hline
\end{tabular}

(b)

\begin{tabular}{cccccc}
\hline Details & $\mathrm{wt} \%$ & $\mathrm{Mn} \%$ & $\mathrm{Fe} \%$ & $\mathrm{SiO}_{2} \%$ & $\mathrm{Mn} \mathrm{Rec. \%}$ \\
\hline Concentrate & 18.5 & 28.3 & 11.2 & 24.2 & 26.0 \\
Middling & 19.9 & 16.0 & 5.0 & 52.4 & 15.9 \\
Tailing & 61.6 & 19.0 & 7.2 & 44.8 & 58.1 \\
Head & 100 & & & & 100 \\
\hline
\end{tabular}

grade siliceous Mn-ore from Bonai-Keonjhar belt exhibits the presence of two dominating but contrasting phases. Pyrolusite and cryptomelane constitute the major manganese phases and quartz as the dominating gangue except for little hematite and kaolinite in the cherty type of Mn-ore. In the case of siliceous crystalline type quartz occurs mostly as disseminated or saccaroidal grains occupying the intergranular space with Mn-phases. The textural analysis of both the samples under microscope revealed that the crystalline type siliceous Mn-ore contains large blades of pyrolusite or thick veins of cryptomelane traversing through silica matrix. Thus these two phases could be liberated well by simple grinding to finer sizes. But in the cherty type Mn-ore cryptocrystalline 
Table 3. (A) Results of the magnetic products of dry magnetic separation (Crystalline type Mn-ore); (B) Results of the magnetic products of dry magnetic separation (Cherty type Mn-ore).

(A)

\begin{tabular}{|c|c|c|c|c|c|c|c|c|c|c|c|c|}
\hline \multirow[b]{2}{*}{ Size, in $\mu \mathrm{m}$} & \multicolumn{4}{|c|}{0.73 tesla } & \multicolumn{4}{|c|}{1.00 tesla } & \multicolumn{4}{|c|}{1.23 tesla } \\
\hline & $\mathrm{wt} \%$ & $\mathrm{Mn} \%$ & $\mathrm{SiO}_{2} \%$ & $\begin{array}{l}\mathrm{Mn} \% \\
\text { recovery }\end{array}$ & $\mathrm{wt} \%$ & $\mathrm{Mn} \%$ & $\mathrm{SiO}_{2} \%$ & $\begin{array}{l}\mathrm{Mn} \% \\
\text { recovery }\end{array}$ & $\mathrm{wt} \%$ & $\mathrm{Mn} \%$ & $\mathrm{SiO}_{2} \%$ & $\begin{array}{l}\mathrm{Mn} \% \\
\text { recovery }\end{array}$ \\
\hline$-1000+500$ & 38.8 & 41.9 & 10.8 & 23.9 & 39.3 & 43.51 & 8.2 & 26.0 & 41.9 & 42.7 & 9.5 & 33.9 \\
\hline$-500+250$ & 33.0 & 44.7 & 6.4 & 21.7 & 32.8 & 45.91 & 4.4 & 23.0 & 32.6 & 44.6 & 6.5 & 27.5 \\
\hline$-250+150$ & 14.2 & 42.9 & 9.2 & 8.9 & 13.8 & 45.91 & 4.5 & 9.7 & 12.4 & 41.5 & 11.4 & 9.7 \\
\hline$-150+75$ & 14.0 & 46.4 & 3.7 & 9.6 & 14.1 & 47.48 & 2.0 & 10.3 & 13.1 & 46.8 & 3.0 & 11.5 \\
\hline Head & 100 & 43.9 & 7.5 & 64.1 & 100 & 45.18 & 4.7 & 69.0 & 100 & 44.0 & 7.6 & 82.6 \\
\hline
\end{tabular}

(B)

\begin{tabular}{|c|c|c|c|c|c|c|c|c|c|c|c|c|}
\hline \multirow[b]{2}{*}{ Size, in $\mu \mathrm{m}$} & \multicolumn{4}{|c|}{0.73 tesla } & \multicolumn{4}{|c|}{1.00 tesla } & \multicolumn{4}{|c|}{1.23 tesla } \\
\hline & $\mathrm{wt} \%$ & $\mathrm{Mn} \%$ & $\mathrm{SiO}_{2} \%$ & $\begin{array}{l}\mathrm{Mn} \% \\
\text { recovery }\end{array}$ & $\mathrm{wt} \%$ & $\mathrm{Mn} \%$ & $\mathrm{SiO}_{2} \%$ & $\begin{array}{c}\mathrm{Mn} \% \\
\text { recovery }\end{array}$ & $\mathrm{wt} \%$ & $\mathrm{Mn} \%$ & $\mathrm{SiO}_{2} \%$ & $\begin{array}{l}\mathrm{Mn} \% \\
\text { recovery }\end{array}$ \\
\hline$-1000+500$ & 50.6 & 27.5 & 28.4 & 12.2 & 52.0 & 31.3 & 16.7 & 13.4 & 51.4 & 30.6 & 17.2 & 18.9 \\
\hline$-500+250$ & 29.4 & 28.4 & 26.6 & 10.4 & 26.8 & 33.3 & 10.3 & 11.9 & 27.8 & 32.1 & 17.2 & 17.3 \\
\hline$-250+150$ & 8.5 & 26.9 & 32.2 & 9.2 & 9.4 & 35.3 & 11.7 & 14.4 & 9.2 & 33.0 & 18.2 & 19.2 \\
\hline$-150+75$ & 11.5 & 29.5 & 27.9 & 10.9 & 11.8 & 34.7 & 12.3 & 14.0 & 11.6 & 33.7 & 15.7 & 19.7 \\
\hline Head & 100 & 28.1 & 28.7 & 42.7 & 100 & 33.6 & 12.7 & 53.7 & 100 & 32.3 & 17.0 & 75.1 \\
\hline
\end{tabular}

silica occurs in mesoscopic layers with Mn-phases and it showed very fine lamination between manganese and silica and also ramifying veins of silica traversing through manganese which is very difficult to liberate even at ultra fine size. This contrasting micro-texture of Mn-phases and gangue is well reflected in their studies on liberation sizes. In the siliceous crystalline type liberation of silica increases with decrease in size while in the cherty type a significant amount of silica remains with Mn-phases even at very fine size $(-150+75 \mu \mathrm{m})$.

The difference between the specific gravities of the two major phases pyrolusite (4.7) and quartz (2.65) was utilized to separate them through tabling studies. At -500 $+150 \mu \mathrm{m}$ size fraction the crystalline type Mn-ore gave a table concentrate having $42 \% \mathrm{Mn}$ at $40 \%$ recovery. The siliceous cherty type did not respond well because of poor liberation.

Beneficiation of medium grade Mn-ore from Chikla, Maharastra, India [3,4] have shown that an ore having $44 \% \mathrm{Mn}$ can be upgraded to $51 \% \mathrm{Mn}$ by wet magnetic separation process. The present authors had also reported the possible upgradation of low-grade siliceous Mn-ore from Bhoot-River side quarry of OMDC lease hold in the Bonai-Keonjhar belt, north Orissa, India [5]. The siliceous crystalline type was upgraded to $45 \% \mathrm{Mn}$ with $69 \%$ recovery at $-150+75 \mu \mathrm{m}$ and 1.0 tesla magnetic intensity. In contrast the cherty type did not respond well to the above experimental setting and could give only $34 \% \mathrm{Mn}$ and containing around $12 \% \mathrm{SiO}_{2}$.

The overall failure of the low-grade siliceous cherty type of Mn-ore from Bonai-Keonjhar belt against the crystalline type was because of poor liberation even at very fine size. The image analysis study of both the siliceous crystalline and cherty type Mn-ores using a electron probe microanalyser (Figure 3) revealed that crystalline type siliceous Mn-ore contain large saccaroidal grains which are well liberated during grinding to finer sizes (below $100 \mathrm{mesh}$ ). But the cherty type displayed intimate association of $\mathrm{Mn}$ minerals and silica even at very fine size $(20 \mu \mathrm{m})$. Thus the distinctive microstructure controls the degree of liberation of the siliceous gangue from manganese matrix and influence the overall beneficiation of two types of low-grade manganese ores from Orissa.

\section{Conclusion}

The upgradation of low-grade siliceous crystalline type manganese ores of Bonai-Keonjhar belt, Orissa, India through dry magnetic separation has opened up new vistas for utilizing such ores otherwise rejected and dumped at mine sites causing both dispersal and environmental hazards. However, detailed mineralogical and microstructural analysis of the low-grade siliceous manganese 

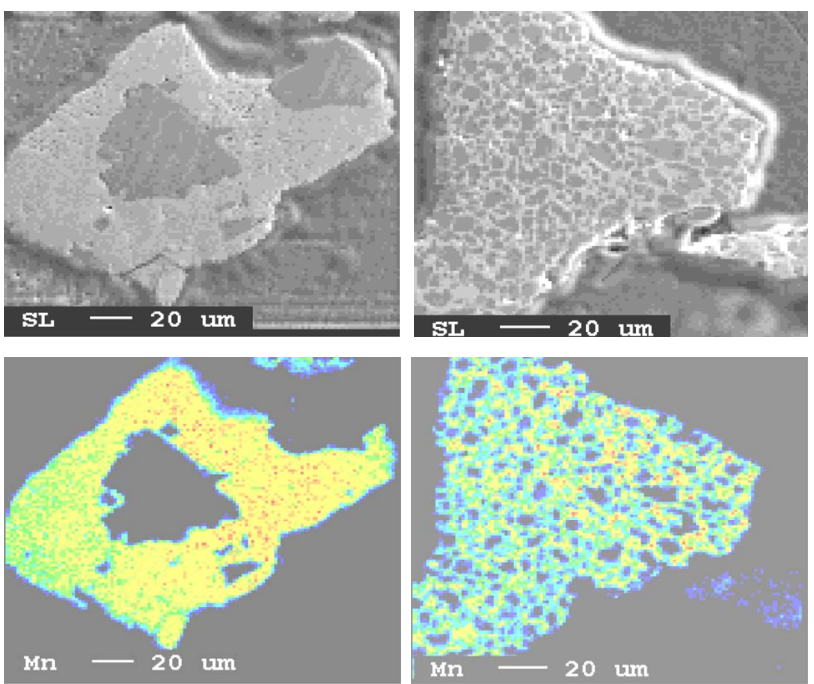

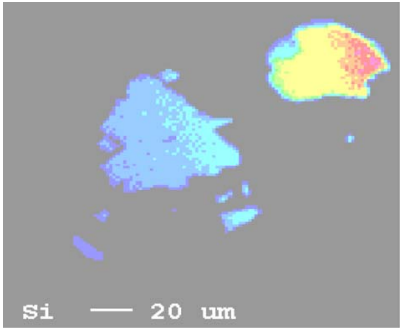

(A)

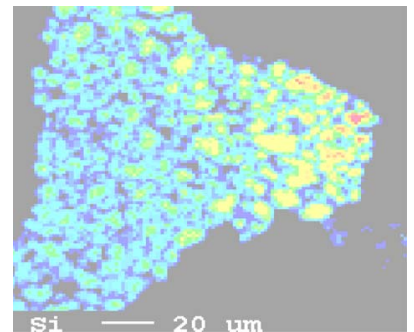

(B)
Figure 3. X-ray image map of low-grade siliceous Mn-ore with respect to $\mathrm{Mn}$ and $\mathrm{Si}$. (A) Siliceous crystalline type; (B) Siliceous cherty type.

ore samples should be taken up before processing to establish the nature of silica matrix i.e. crystalline or cherty. The cherty type of siliceous Mn-ore needs to be demarcated in the field and should be avoided during exploita- tion or blended in suitable proportion with crystalline type Mn-ore to get a desired grade after beneficiation.

\section{Acknowledgements}

The authors are highly thankful to the Director, Institute of Minerals and Materials Technology, Bhubaneswar for his kind permission to publish this paper. The authors are also thankful to the Department of Science \& Technology, New Delhi, India for their financial support in the form of a project (ESS/23/VES/043/99).

\section{REFERENCES}

[1] P. P. Mishra, "Mineralogical and Geochemical Studies on Manganese Ores from Roida Region, Keonjhar Dist, Orissa with Special Reference to Their Optimum Utilization," Unpublished Thesis, Utkal University, Orissa, 2005.

[2] Indian Mineral Year Book, "Manganese Ores," Indian Bureau of Mines Publications, Nagpur, 2007, pp. 1-21.

[3] G. V. Rao, B. K. Mohapatra and A. K. Tripathy, "Enrichment of the Manganese Content by Wet High Intensity Magnetic Separator from Chikla Manganese Ore, India," Magnetic and Electrical Separation, Vol. 9, No. 2, 1988, pp. 69-82. doi:10.1155/1998/45169

[4] B. K. Mohapatra, D. S. Rao and R. K. Sahu, "Characterisation and Magnetic Separation Studies on Chikla Manganese Ore, Maharastra," Indian Mining and Engineering Journal, 1995, pp. 37-41.

[5] P. P. Mishra, B. K. Mohapatra and K. Mahanta, "Upgradation of Low-Grade Siliceous Manganese Ore from Bonai-Keonjhar Belt, Orissa, India," Journal of Minerals \& Materials Characterization and Engineering, Vol. 8, No. 1, 2009, pp. 47-56. 